\title{
Pengembangan Aplikasi untuk Optimasi Jenis Kendaraan dan Penentuan Rute pada Perusahaan Tranportasi
}

\author{
Cindy Himawan \\ Information System Study Program, President University \\ cindy.himawan@gmail.com
}

\begin{abstract}
Transportation Management System is very needed in optimize efficiency and effectiveness on logistics company. One of the most important part of transportation management system is determining delivery route from a depot to each customer. A lot of studies have been done about determining the best route in a shipping ritation with various algorithms. In the previous research, determination of delivery route is done without any implementation in the application. During the route determination is still done manually it will make a flow process in the company is not maximize. Model development aims to make an implementation application that serves to determine delivery route based on the problem of vehicle routing problem using the nearest neighbour method which is restricted to heavy loads in the transportation. Implementation of route determination an application will be done based on business process in transportation company, named PT. X, so it is necessary to observe the company. Compared to previous research, this research will determine delivery route in application based on the problem of vehicle routing problem using the nearest neighbour method.
\end{abstract}

Keywords - Transportation Management System, Application, Nearest Neighbour, Vehicle Routing Problem, Route.

\section{INTRODUCTION}

According to Nolan and Croson [1], the transformation of a company system is caused by the rapid development of information technology. This is because very rapid technological changes have an important role in supporting the survival of the company. According to Hammer and Champy [2], information technology is one indicator of technological development which acts as a catalyst for the formation and rearrangement of organizations where $90 \%$ of companies whose Business Process Reengineering is unsuccessful due to errors do not implement information technology as enablers. The success of Business Process Reengineering is largely determined by the creative use of information technology.

According to Gita Anggaranie [3], in this technological era the challenge of a company engaged in logistics is how to deliver products to consumers on time, without defects effectively and efficiently. The term logistics covers much broader aspects such as warehousing, inventory management, billing, purchasing, packaging, labeling, shipping, payment, demand forecasting, transfer of goods, and return of return goods. According to Zaroni [4], transportation plays an important role in a company's supply chain management. $60 \%$ of the company's total logistics costs are transportation costs. The accuracy of the delivery of goods will help the company to reduce the supply of goods, the cost of storage, and the transfer of goods.

Transportation Management System is an information technology that is used to plan, optimize, and execute all transportation activities. The Transportation Management System can help transport management activities of a company that occur before, during, and after transportation movements by optimizing the flow of goods in various facilities, tracking the delivery of goods in transit, and managing the process of payment of shipping goods. Concerns about drastically increasing costs, lack of capacity, and increasing complexity in transportation management are the main reasons that transportation management system technology is not implemented.

The problem that often occurs in third party logistics companies, especially PT. X, is the determination of routes that only rely on the operator's experience in previous shipments so that it requires a long computing time to produce an optimal local route solution. The old computing time is closely related to the speed in fulfilling each sales order made by the company. It is said to be closely related, of course, the longer the fulfillment of sales orders made by the company, it will cause the possibility of many backorder. Automation with technology in every routing process carried out by PT. $X$ is the goal to be achieved by all third party logistics companies including PT. X.

The transportation management system succeeded in becoming one of the answers to these problems in the development of information technology that was very rapid. According to Adriansyah [5], the transportation management system functions as something related to the production, distribution and exchange of wealth or products that can all be obtained and are useful.

Determination of a shipping route is one part of the transportation management system, which can be determined by various methods. One method that can be used is the 


\section{IT FOR SOCIETY, Vol. 03, No. 01 ISSN 2503-2224}

nearest neighbor method. This method is quite often used by users because this method is quite easy to do. Determination of distance in this method is enough to see the closest distance from a starting point to predetermined destinations. However, a method is not necessarily in accordance with all types of delivery ritase. This depends on the limitations that exist on a shipment in the company. Therefore this study will examine whether the nearest neighbor method can provide optimal local route solutions with short computing time on the development of transportation management system applications based on the business flow process at PT.X.

\section{RESEARCH METHODOLOGY}

\section{A. Company Background}

PT. $\mathrm{X}$ is a company engaged in transportation services, which consists of three core services, namely lease units, direct transporters, and transport distribution multi-drop.

\section{Lease Unit}

The lease unit is a direct leasing to the customer. The leasing process is carried out directly by the customer to TTP for the duration specified by the two parties.

\section{Direct Transporter}

Direct transport is a type of service offered by TTP in the form of moving goods from one origin point to one dropoff point.

\section{Transport Distribution Multi-Drop}

Multi-drop transport distribution is a type of service offered by TTP in the form of moving goods from one origin point to several drop-off points based on customer orders.

\section{B. Actor}

Business processes that occur at PT. X involve several parties, namely PT. X customers, field management, PT. X, and stores. Customer PT. X conducts collection, picking, packing, and loading process activities. Field management has the task of conducting the routing process in a shipment, PT. X conducts invoicing and delivering activities. The last party is the store to carry out goods receiving activities as well as defective returns.

\section{Business Process}

The following is a business process that occurs at PT. X, customers, vendors, and stores are as follows.

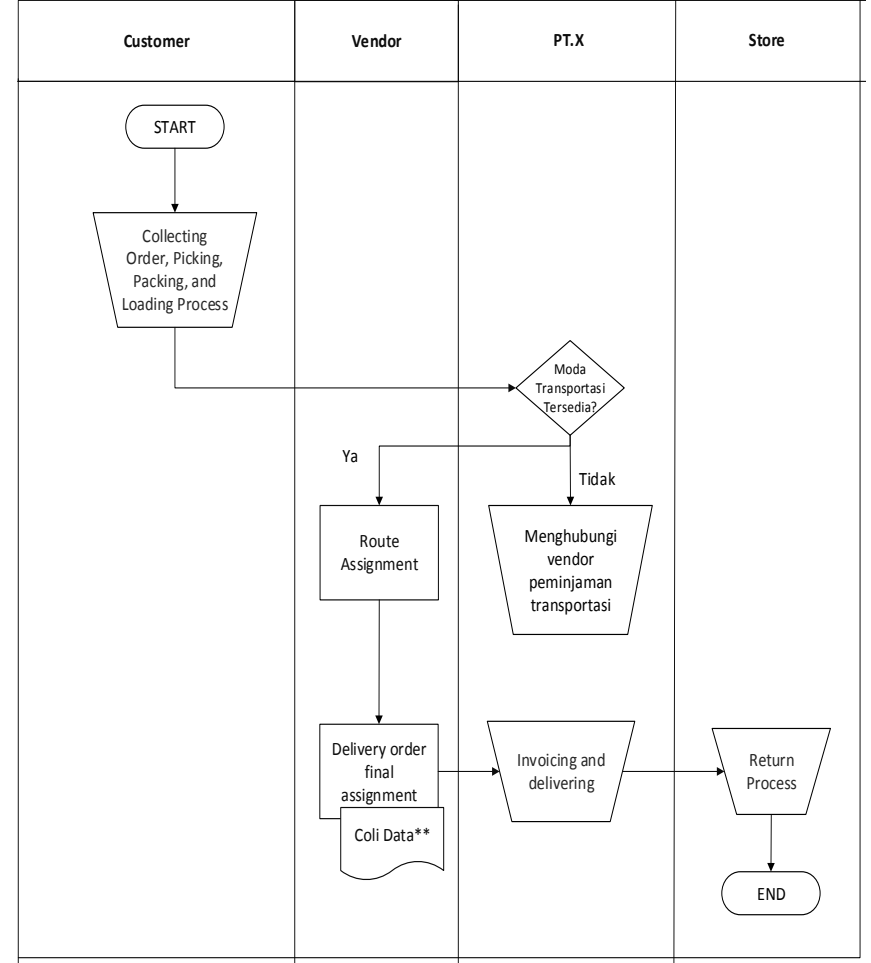

Fig 1 Business Process in PT X

\section{Transportation Mode}

Transportation mode is a unit used by PT. $X$ in making a shipment. The mode of transportation used by PT. X can be in the form of own transportation mode or rental mode of transportation to vendors working with PT. X. Each unit used by PT. X has been equipped with a safety box / bullet box as a place to store money from shops and other documents. PT. X has four transportation modes that are used, among others:

1. Colt Box L300

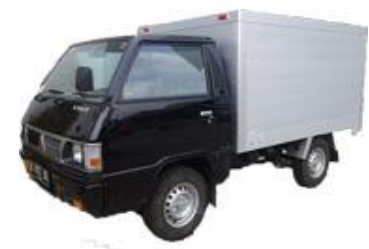

Fig 1 Colt Box L300

\section{Colt Diesel Engkel FE71}




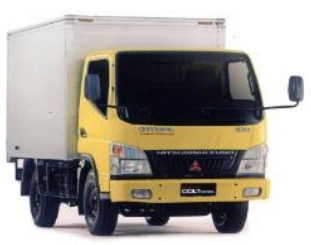

Fig 2 Colt Diesel Engkel FE71

3. Colt Diesel Double FE73

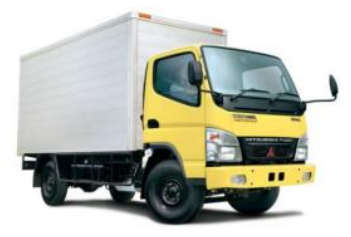

Fig 3 Colt Diesel Double FE73

4. Fuso

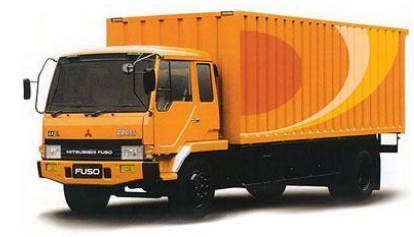

Fig 4 Fuso

\section{E. Procedure}

Based on the above data collection, there are several procedures or steps to analyze the distance and computation time generated by the transportation management system application with manual calculations at PT.X.

1. Determining the Scope of the Business Process

2. Determination of the Main Activities of the Application

3. Data Analysis

4. Translation of Main Activity Details

5. Determination of Data Flow Movements

6. Application Development

\section{RESULT}

The transportation management system application developed will be based on the business process that is being used by PT. X. The first step in data processing is to determine the scope of the business process that will be developed in the transportation management system application. The scope of business processes used in the development of transportation management system applications can be seen in Figure 1. The following is a business description of the route determination process when using a transportation management system application.

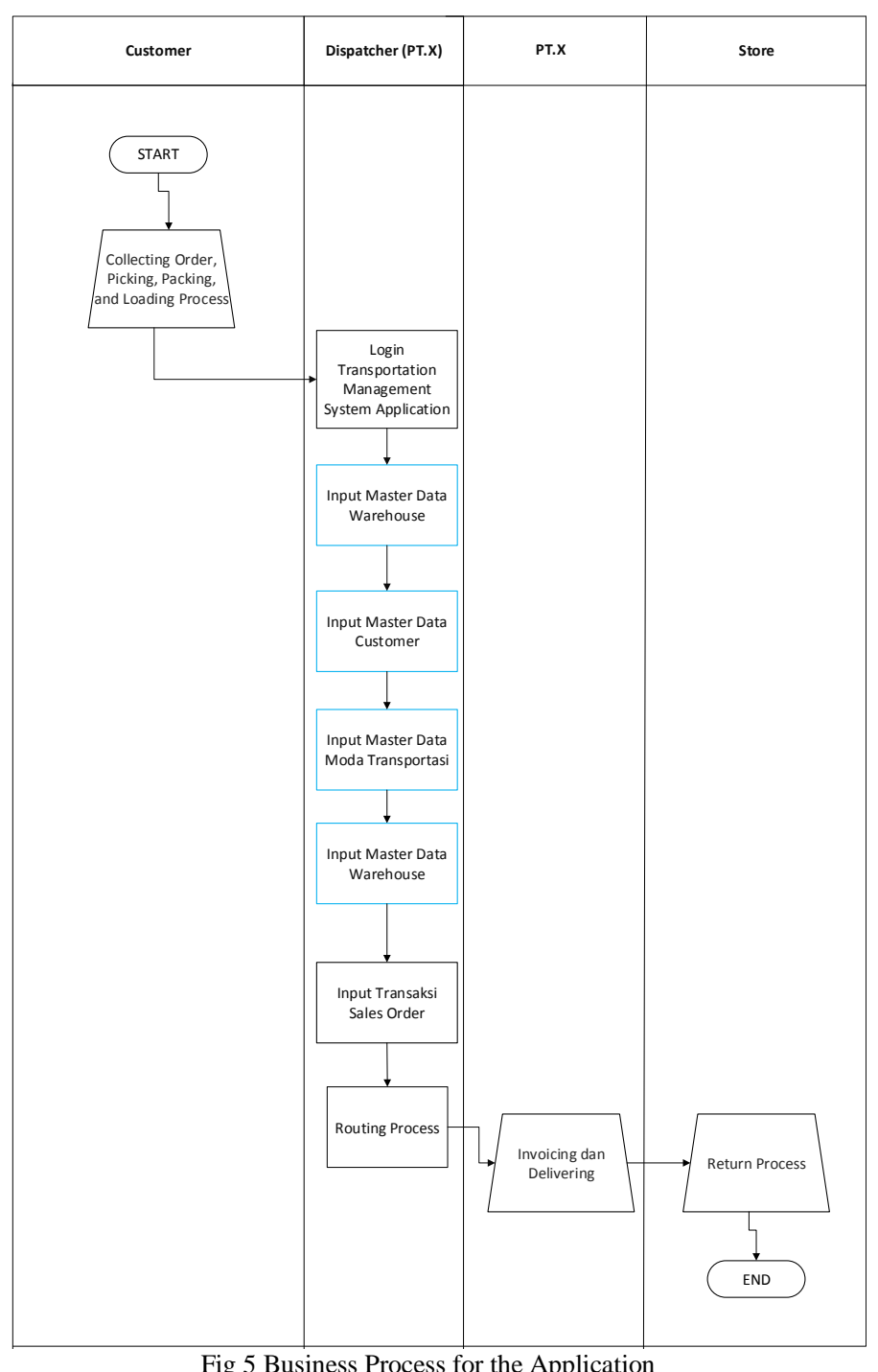

The second step in processing data is determining the main activities that exist in the transportation management system application. The main activity developed in the application aims at fulfilling the routing process which is the main goal in the development of this application. Determination of the main activities can be seen in Figure7. 


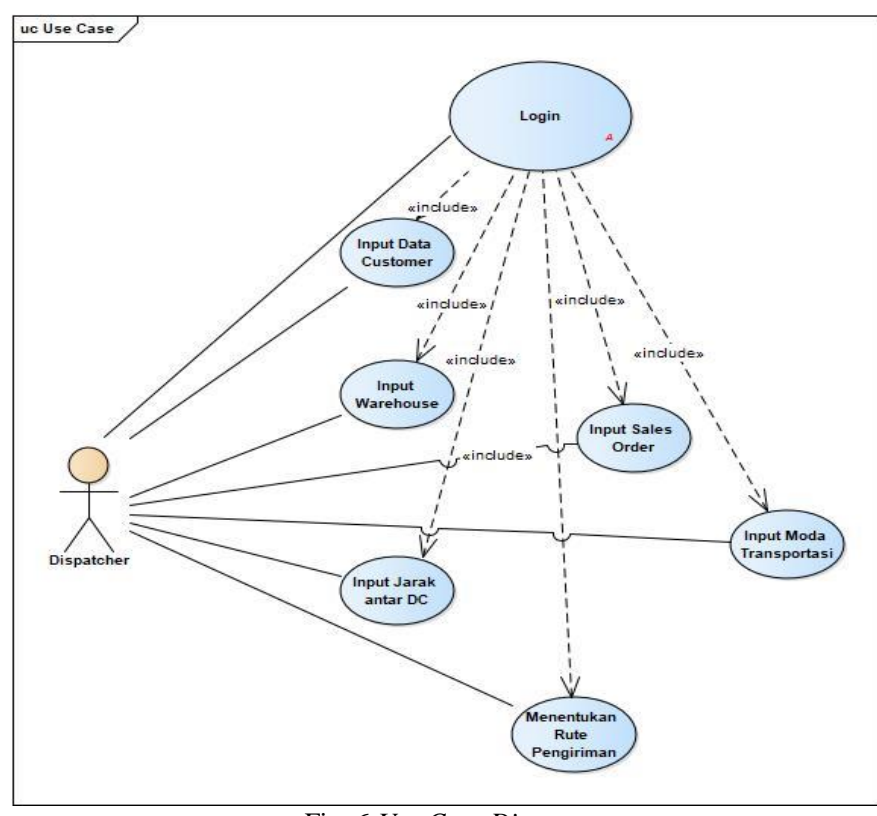

Fig 6 Use Case Diagram

The third step is the analysis of input, output, and database data used in the developed application program. Data analysis is done by creating a class diagram. Class Diagrams can be seen in Figure 8.

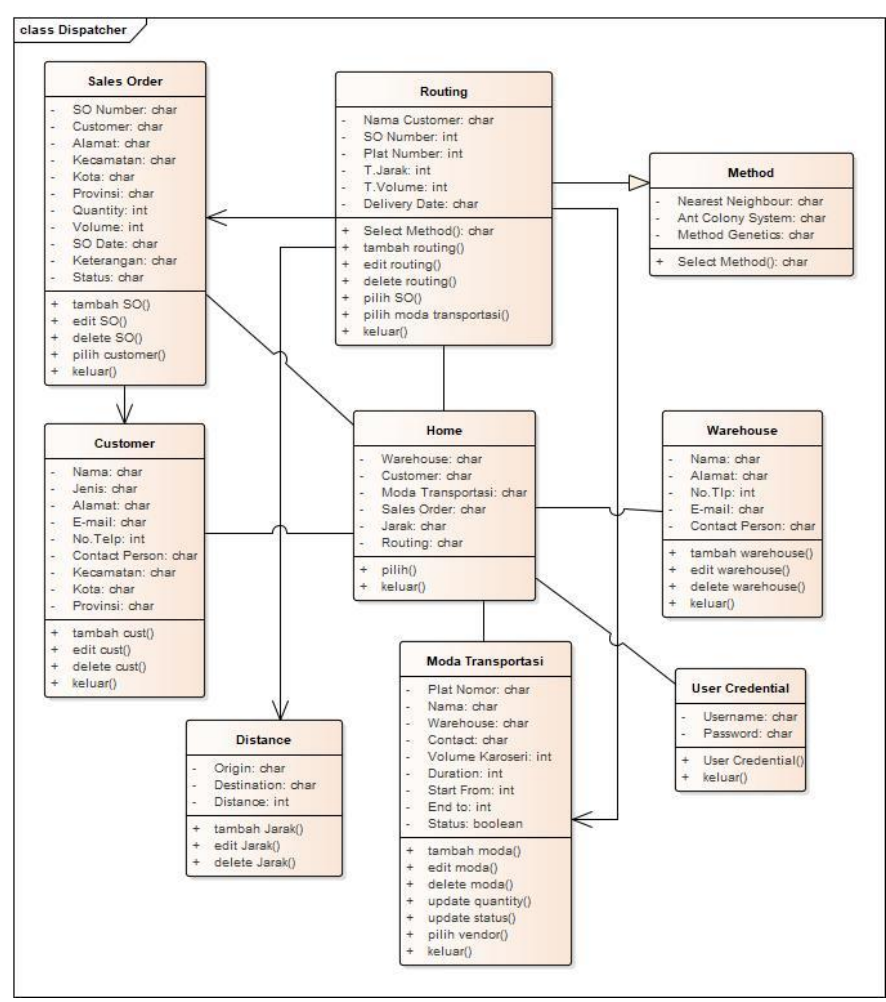

Fig 7 Class Diagram
The fourth step in processing data is to describe all the main activities in the use case diagram. This aims to clarify the activities that will occur in the application. The description of the main activities is done by making activity diagrams. The fifth step in data processing is determining the movement of data flow in the transportation management system application. Determination of data flow in the transportation management system application is done by making sequence diagrams.

After the data use case diagrams, class diagrams, activity diagrams, and sequence diagrams have been processed, the next step is the development of transportation management system applications to adjust to these data.

When a transportation management system application has been developed, testing of each application function will be carried out. Testing applications is based on use case diagrams and business processes, whether applications are developed in accordance with the use case diagram and business processes that have been made. Application testing can be seen in Table I and Table II.

After successful application testing, the comparative analysis of distance and computation time in a route determination using the application by determining the route with manual calculations can be done. Testing is done by making 4 test cases where each case has a different number of stores. Each case will be calculated the calculation of distance through the application compared to the possibility of other routes that can be formed by PT.X. In addition to distance, computational time through applications with computational time with manual calculations will be compared to strengthen the reason for PT. $\mathrm{X}$ to use a transportation management system application.

The four test cases carried out have a different number of stores where the first case test has a number of stores, the second case has a number of two stores, the third case has a number of three stores, and the fourth case has a number of four stores. The results of the comparison of the calculation of distance and computation time in each test case can be seen in Table III, Table IV, Table V, and Table VI.

TABLE I APPLICATION TESTING (1)

\begin{tabular}{|c|c|c|c|}
\hline Actor & $\begin{array}{c}\text { Business } \\
\text { Process }\end{array}$ & Use Case & $\begin{array}{c}\text { Application } \\
\text { Menu }\end{array}$ \\
\hline $\begin{array}{c}\text { Routing } \\
\text { Process }\end{array}$ & $\begin{array}{c}\text { Input } \\
\text { Customer }\end{array}$ & $\begin{array}{c}\text { Input } \\
\text { Customer }\end{array}$ & Input Customer \\
\hline & $\begin{array}{c}\text { Input } \\
\text { Warehouse }\end{array}$ & $\begin{array}{c}\text { Input } \\
\text { Warehouse }\end{array}$ & $\begin{array}{c}\text { Input } \\
\text { Warehouse }\end{array}$ \\
\hline & $\begin{array}{c}\text { Input Moda } \\
\text { Transportasi }\end{array}$ & $\begin{array}{c}\text { Input Moda } \\
\text { Transportasi }\end{array}$ & $\begin{array}{c}\text { Input Moda } \\
\text { Transportasi }\end{array}$ \\
\hline & $\begin{array}{c}\text { Input } \\
\text { Distance }\end{array}$ & Input Distance & Input Distance \\
\hline
\end{tabular}


IT FOR SOCIETY, Vol. 03, No. 01

ISSN 2503-2224

\begin{tabular}{|c|c|c|c|}
\hline $\begin{array}{c}\text { Input Sales } \\
\text { Order }\end{array}$ & $\begin{array}{c}\text { Input Sales } \\
\text { Order }\end{array}$ & $\begin{array}{c}\text { Input Sales } \\
\text { Order }\end{array}$ \\
\hline Routing & Routing & Routing \\
\hline
\end{tabular}

\begin{tabular}{c|c|c|c} 
Method & - & - & Nearest \\
Neighbour
\end{tabular}

TABLE II

APPLICATION TESTING (2)

\begin{tabular}{|c|c|c|c|c|}
\hline Use Case & Test Case & Test Title & $\begin{array}{c}\text { Test Summary } \\
\end{array}$ & Result \\
\hline Login & 001 & User Login & $\begin{array}{l}\text { Test whether the user can log in to the } \\
\text { application when entering the correct } \\
\text { username and password }\end{array}$ & Success \\
\hline Input Warehouse & 002 & Input Warehouse & $\begin{array}{l}\text { Test whether the user can do the input } \\
\text { warehouse in the application and store it } \\
\text { in the warehouse table }\end{array}$ & Success \\
\hline Input Customer & 003 & Input Customer & $\begin{array}{l}\text { Test whether the user can enter } \\
\text { customer input on the application and } \\
\text { save it in the customer table }\end{array}$ & Success \\
\hline Input Moda Transportasi & 004 & $\begin{array}{l}\text { Input Moda } \\
\text { Transportasi }\end{array}$ & $\begin{array}{l}\text { Test whether the user can input } \\
\text { transport modes in the application and } \\
\text { store them in the transportation mode } \\
\text { table }\end{array}$ & Success \\
\hline Input Distance & 005 & Input Distance & $\begin{array}{l}\text { Test whether the user can input distance } \\
\text { to the application and save it in the } \\
\text { distance table }\end{array}$ & Success \\
\hline Input Sales Order & 006 & Input Sales Order & $\begin{array}{l}\text { Test whether the user can input sales } \\
\text { orders on the application and save them } \\
\text { in the sales order table }\end{array}$ & Success \\
\hline Select Sales Order & 007 & Select Sales Order & $\begin{array}{l}\text { Test whether the user can select the } \\
\text { sales order on the application in the } \\
\text { route determination step }\end{array}$ & Success \\
\hline Select Moda Transportasi & 008 & $\begin{array}{l}\text { Select Moda } \\
\text { Transportasi }\end{array}$ & $\begin{array}{l}\text { Test whether the user can select the } \\
\text { mode of transportation in the } \\
\text { application in the route determination } \\
\text { step }\end{array}$ & Success \\
\hline Routing & 009 & Routing & $\begin{array}{l}\text { Test whether the user can route the } \\
\text { application and save it in the routing } \\
\text { table }\end{array}$ & Success \\
\hline
\end{tabular}

TABLE III

DISTANCE AND COMPUTATION - CASE 1

\begin{tabular}{|c|c|c|c|c|}
\hline Route & Distance & Method & $\begin{array}{c}\text { Manual Time } \\
\text { Computation (s) }\end{array}$ & $\begin{array}{c}\text { Time Computation by } \\
\text { Application (s) }\end{array}$ \\
\hline PT. X - Cust A - PT. X & 22 & Nearest Neighbour & 39.6 & 2.86 \\
\hline
\end{tabular}

TABLE IV

DISTANCE AND COMPUTATION - CASE 2

\begin{tabular}{|c|c|c|c|c|}
\hline Route & Distance & Method & $\begin{array}{c}\text { Manual Time } \\
\text { Computation (s) }\end{array}$ & $\begin{array}{c}\text { Time Computation by } \\
\text { Application (s) }\end{array}$ \\
\cline { 1 - 3 } PT. X - Cust A - Cust B- PT. X & 10 & Nearest Neighbour & 90 & 2.51 \\
\cline { 1 - 2 } PT. X - Cust A - Cust B- PT. X & 10 & Manual Calculation & & \\
\hline
\end{tabular}


IT FOR SOCIETY, Vol. 03, No. 01

ISSN 2503-2224

TABLE V

DISTANCE AND COMPUTATION - CASE 3

\begin{tabular}{|c|c|c|c|c|}
\hline Route & Distance & Method & $\begin{array}{l}\text { Manual Time } \\
\text { Computation (s) }\end{array}$ & $\begin{array}{c}\text { Time } \\
\text { Computation } \\
\text { by Application } \\
\text { (s) } \\
\end{array}$ \\
\hline $\begin{array}{c}\text { PT. X - MW - MW2 - Cibaduyut - } \\
\text { PT. X }\end{array}$ & 26 & Nearest Neighbour & \multirow{6}{*}{327} & \multirow{6}{*}{2.87} \\
\hline $\begin{array}{c}\text { PT. X - MW - Cibaduyut - MW2 - } \\
\text { PT. X }\end{array}$ & 26 & Manual Calculation & & \\
\hline $\begin{array}{c}\text { PT. X - MW2 - Cibaduyut - MW - } \\
\text { PT. X }\end{array}$ & 26 & Manual Calculation & & \\
\hline $\begin{array}{c}\text { PT. X - MW2 - MW - Cibaduyut - } \\
\text { PT. X }\end{array}$ & 26 & Manual Calculation & & \\
\hline $\begin{array}{c}\text { PT. X - Cibaduyut - MW2 - MW - } \\
\text { PT. X }\end{array}$ & 26 & Manual Calculation & & \\
\hline $\begin{array}{c}\text { PT. X - Cibaduyut - MW - MW2 - } \\
\text { PT. X }\end{array}$ & 26 & Manual Calculation & & \\
\hline
\end{tabular}

TABLE VI

DISTANCE AND COMPUTATION - CASE 4

\begin{tabular}{|c|c|c|c|c|}
\hline Route & Distance & Method & $\begin{array}{c}\text { Manual Time Computation } \\
\text { (s) }\end{array}$ & $\begin{array}{c}\text { Time } \\
\text { Computation } \\
\text { by } \\
\text { Application } \\
\text { (s) }\end{array}$ \\
\hline $\begin{array}{c}\text { PT. X - MW - KC } 1 \text { - KA - KC } 2 \text { - PT. } \\
\text { X }\end{array}$ & 27 & $\begin{array}{c}\text { Nearest } \\
\text { Neighbour }\end{array}$ & \multirow{17}{*}{1563} & \multirow{17}{*}{2.52} \\
\hline $\begin{array}{c}\text { PT. X - MW - KC } 1 \text { - KC } 2 \text { - KA - PT. } \\
\text { X }\end{array}$ & 28 & $\begin{array}{c}\text { Manual } \\
\text { Calculation }\end{array}$ & & \\
\hline $\begin{array}{c}\text { PT. X - MW - KC } 2 \text { - KA - KC } 1 \text { - PT. } \\
\text { X }\end{array}$ & 27 & $\begin{array}{c}\text { Manual } \\
\text { Calculation }\end{array}$ & & \\
\hline $\begin{array}{c}\text { PT. X - MW - KC } 2 \text { - KC } 1 \text { - KA - PT. } \\
\text { X }\end{array}$ & 27 & $\begin{array}{c}\text { Manual } \\
\text { Calculation }\end{array}$ & & \\
\hline $\begin{array}{c}\text { PT. X - MW - KA - KC } 1 \text { - KC } 2 \text { - PT. } \\
\text { X }\end{array}$ & 28 & $\begin{array}{c}\text { Manual } \\
\text { Calculation }\end{array}$ & & \\
\hline $\begin{array}{c}\text { PT. X - MW - KA - KC } 2 \text { - KC } 1 \text { - PT. } \\
\text { X }\end{array}$ & 28 & $\begin{array}{c}\text { Manual } \\
\text { Calculation }\end{array}$ & & \\
\hline $\begin{array}{c}\text { PT. X - KA - MW - KC } 1 \text { - KC } 2 \text { - PT. } \\
\text { X }\end{array}$ & 31 & $\begin{array}{c}\text { Manual } \\
\text { Calculation }\end{array}$ & & \\
\hline $\begin{array}{c}\text { PT. X - KA - MW - KC } 2 \text { - KC } 1 \text { - PT. } \\
\text { X }\end{array}$ & 31 & $\begin{array}{c}\text { Manual } \\
\text { Calculation }\end{array}$ & & \\
\hline $\begin{array}{c}\text { PT. X - KA - KC } 1 \text { - MW - KC } 2 \text { - PT. } \\
\text { X }\end{array}$ & 30 & $\begin{array}{c}\text { Manual } \\
\text { Calculation }\end{array}$ & & \\
\hline $\begin{array}{c}\text { PT. X - KA - KC } 1 \text { - KC } 2 \text { - MW - PT. } \\
\text { X }\end{array}$ & 28 & $\begin{array}{c}\text { Manual } \\
\text { Calculation }\end{array}$ & & \\
\hline $\begin{array}{c}\text { PT. X - KA - KC } 2 \text { - MW - KC } 1 \text { - PT. } \\
\text { P }\end{array}$ & 30 & $\begin{array}{c}\text { Manual } \\
\text { Calculation }\end{array}$ & & \\
\hline $\begin{array}{c}\text { PT. X - KA - KC } 2 \text { - KC } 1 \text { - MW - PT. } \\
\text { X }\end{array}$ & 28 & $\begin{array}{c}\text { Manual } \\
\text { Calculation }\end{array}$ & & \\
\hline $\begin{array}{c}\text { PT. X - KC } 1 \text { - KC } 2 \text { - KA - MW - PT. } \\
\text { X }\end{array}$ & 28 & $\begin{array}{c}\text { Manual } \\
\text { Calculation }\end{array}$ & & \\
\hline PT. X - KC 1 - KC 2 -MW - KA - PT. & 31 & $\begin{array}{l}\text { Manual } \\
\text { Calculation }\end{array}$ & & \\
\hline $\begin{array}{c}\text { PT. X - KC } 1 \text { - KA - MW - KC } 2 \text { - PT. } \\
\text { X }\end{array}$ & 30 & $\begin{array}{c}\text { Manual } \\
\text { Calculation }\end{array}$ & & \\
\hline $\begin{array}{c}\text { PT. X - KC } 1 \text { - KA - KC } 2 \text { - MW - PT. } \\
\text { X }\end{array}$ & 27 & $\begin{array}{c}\text { Manual } \\
\text { Calculation }\end{array}$ & & \\
\hline $\begin{array}{c}\text { PT. X - KC } 1 \text { - MW - KA - KC } 2 \text { - PT. } \\
\text { X }\end{array}$ & 30 & $\begin{array}{c}\text { Manual } \\
\text { Calculation }\end{array}$ & & \\
\hline
\end{tabular}


IT FOR SOCIETY, Vol. 03, No. 01

ISSN 2503-2224

\begin{tabular}{|c|c|c|} 
PT. X - KC 1 - MW - KC 2 - KA - PT. & 30 & $\begin{array}{c}\text { Manual } \\
\text { Calculation }\end{array}$ \\
\hline $\begin{array}{c}\text { PT. X - KC } 2 \text { - KC } 1 \text { - KA - MW - PT. } \\
\text { X }\end{array}$ & 28 & $\begin{array}{c}\text { Manual } \\
\text { Calculation }\end{array}$ \\
\hline $\begin{array}{c}\text { PT. X - KC 2 - KC 1 -MW - KA - PT. } \\
\text { PT. X - KC 2 - KA - MW - KC 1 - PT. } \\
\text { X }\end{array}$ & 31 & $\begin{array}{c}\text { Manual } \\
\text { Calculation }\end{array}$ \\
\hline $\begin{array}{c}\text { PT. X - KC 2 - KA - KC 1 - MW - PT. } \\
\text { X }\end{array}$ & 27 & $\begin{array}{c}\text { Manual } \\
\text { Calculation }\end{array}$ \\
\hline $\begin{array}{c}\text { Manual } \\
\text { Calculation }\end{array}$ \\
\hline $\begin{array}{c}\text { PT. X - KC } 2 \text { - MW - KA - KC 1 - PT. } \\
\text { PT. X - KC 2 - MW - KC 1 - KA - PT. } \\
\text { X }\end{array}$ & 30 & $\begin{array}{c}\text { Manual } \\
\text { Calculation }\end{array}$ \\
\hline
\end{tabular}

The distance generated in the 4 test cases is the optimal local distance. However, the distance generated cannot be a strong reason for PT. X to use a transportation management system application. This can be seen in Table VII where the route generated by the application does not make the best route compared to the possible route determined by the field management section. Therefore this study will compare the computation time of route if using an application using manual calculation. In Table VIII it can be seen that the time generated by the application does not require a long time in determining the route. The more stores that are carried out in a shipment, the longer it will take to determine the route with manual calculations. While the time required for the determination of the optimal local route is 3 seconds.

TABLE VII

DISTANCE COMPARISON AND TIME COMPUTATION AND CALCULATION OF MANUAL

\begin{tabular}{|c|c|c|c|}
\hline $\begin{array}{c}\text { Cust } \\
\text { No }\end{array}$ & Distance & $\begin{array}{c}\text { Manual } \\
\text { Time } \\
\text { Computation } \\
\text { (s) }\end{array}$ & $\begin{array}{c}\text { Time } \\
\text { Computation } \\
\text { by } \\
\text { Application } \\
\text { (s) }\end{array}$ \\
\hline 1 & 22 & 39.6 & 2.86 \\
\hline 2 & 10 & 90 & 2.51 \\
\hline 3 & 26 & 327 & 2.87 \\
\hline 4 & 27 & 1563 & 2.52 \\
\hline
\end{tabular}

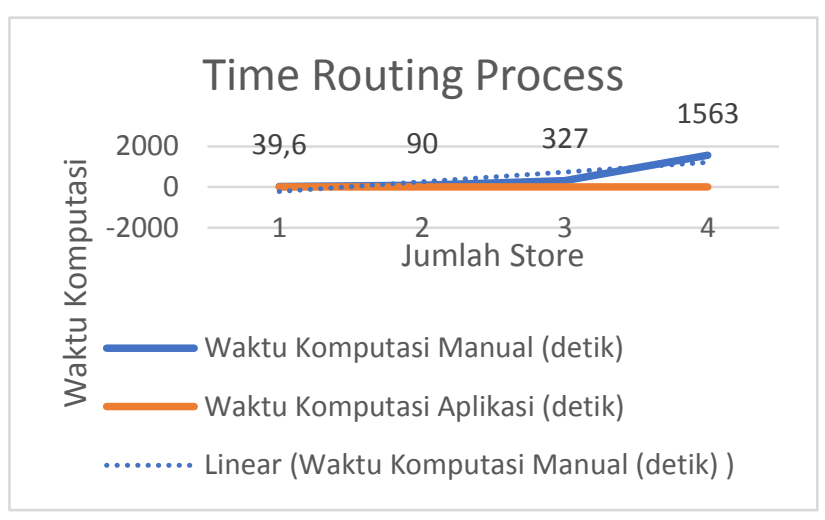

Fig 8 Comparison of Manual Computing Time Charts with Application Computing Time

\section{IV.SUMMARY}

Based on the results of data processing and analysis of distance calculations from several cases, it can be concluded several things related to the research that has been done as follows:

1. The transportation management system application was successfully developed based on the PT.X business process by implementing the nearest neighbor method. This is evidenced by the success of testing on the application menu

2. The nearest neighbor method succeeded in producing the most consistent distance route method and short computing time. This is evidenced by testing the comparison of the calculation results of the route and the computation time generated by the application using the nearest neighbor method with a manual calculation route. Of the nine cases, the calculation results from the application show the optimal local route by making it a minimum route and a very short computing time when compared with manual calculations.

3. The transportation management system application can be used at PT. X because the application already has a menu that includes the business process of determining routes and can 
IT FOR SOCIETY, Vol. 03, No. 01

ISSN 2503-2224

produce optimal local routes and short computing time as needed at PT.X

\section{REFERENCES}

[1] Nolan, Richard L., and Davis C. Croson, Creative Destruction. (1995). A Six Stage Process for Transformation $\mathrm{n}$ the Organization, Harvard Bussiness School Press, Boston, MA

[2] Hammer, Michael and Champy, James. (1993). Reengineering the Corporation: A Manifesto for Business Revolution. Harper Business

[3] Anggaranie, G. (2017, August 19). Permasalahan Logistik dalam E-Commerce. supplychainindonesia.com

[4] Zaroni. (2017). Logistics \& Supply Chain. Jakarta.

[5] Adriansyah., M.Si. (2015). Manajemen Transportasi Dalam Kajian Dan Teori. Jakarta. Fakultas Ilmu Sosial dan Ilmu Politik

[6] Griffis, S. E. and Goldsby, T. J. (2007). Transportation Management System: An Exploration of Progress and Future Prospects, Journal of Transportation Management, $18,18-33$

[7] M. Amri, A. Rahman, dan R. Yuniarti. Penyelesaian Vehicle Routing Problem Dengan Menggunakan Ketode Nearest Neighbour. Malang

[8] Toth dan Vigo. (Ed). 2002. "Vehicle Routing Problem", Philadelphia, SIAM Monographs on Discrete Mathematics and Application

[9] A. Riyanto, Rispianda, dan F.H. Mustofa. 2014. Usulan Perbaikan Rute Pengiriman Dengan Menggunakan Metode Nearest Neighbour dan Branch and Bound di Home Industry Donat Enak Bandung. Bandung. Jurnal Online Institut Teknologi Nasional

[10] Laporte G, Semet, F.2002. Classical Heuristics for The Capacitated VRP. Di Dalam Toth P, Vigo D, Editor. The Vehicle Routing Problem, Philadelphia: Siam.Hlm 109128 .

[11] Braysy O, Grendreau M.2005. Vehicle Routing Problem with Time Windows.Part I: Route Construction and Local Search Algorithm. Transportation Science 39 (1):104-118

[12] Aswar, Wahyuda, dan M.E. Isharyani. Penerapan Metode Nearest Neighbour Untuk Menentukan Rute Distribusi Roti Tawar Citarasa Bakery PT. KMBU Bontang. Samarinda.

[13] Rosa A.S, M. S. (2013). Rekayasa Perangkat Lunak Terstruktur Dan Berorientasi Objek. Bandung.

[14] Aminudin. (2015). Cara Efektif Belajar Framework Laravel. Yogyakarta.

[15] Arief, M. Rudianto. (2011). Pemograman Web Dinamis Menggunakan Php dan Mysql. Yogyakarta: ANDI.

[16] Agus, Saputra. (2011). Pemograman CSS untuk Pemula. Jakarta: PT. Elex Media Komputindo

[17] Sole, A. D. (2016). Visual Studio Code. Syncfusion, Inc.

[18] Wahono, S. D. (2003). Pengantar Unified Modeling Languange. Ilmu Komputer.

[19] M. Amri, A. Rahman, dan R. Yuniarti. Penyelesaian Vehicle Routing Problem Dengan Menggunakan Ketode Nearest Neighbour. Malang 